\title{
An Analysis of Professional Teachers' Questions in EFL Classroom
}

\author{
Shelly Nevtria \\ University of Bengkulu \\ Shellynevtriajd@yahoo.co.id \\ Mulyadi \\ University of Bengkulu \\ ladunimulyadi@gmail.com \\ Hilda Puspita \\ University of Bengkulu \\ puspita.hilda@gmail.com
}

\begin{abstract}
Corresponding author: Shelly Nevtria ( $\square$ Email: Shellynevtriajd@yahoo.co.id $)$
\end{abstract}
\begin{abstract}
In English language classroom, teachers' questions are important parts of teaching English language. Teachers need to know what kind of questions which potentially support students learning the target language. However, students did not actively participate in learning particularly when responding to teachers' questions. To overcome this problem, it is important for teachers to modify their questions through some techniques in order to get students' responses. This study reports the types of teachers' questions used by English teachers in the classroom. This research was descriptive quantitative research. The research was conducted at the tenth grade of SMA N 5 Bengkulu. The data were collected through observation and video recording. The teachers' questions were analyzed using types according to Taxonomy Blooms revised by Anderson and Krathwohl (2001). The research findings show that both teachers the English teachers only used three from the six types. Namely, remembering, understanding, and analyzing questions. The types that did not appear were applying, evaluating, and creating questions. The modification of modifying questions are repeating and rephrasing. The dominant of remembering questions and how teachers modified the questions are influenced by teachers' competence, students' competence, a situation of teaching English language, and teaching material.
\end{abstract}

Keywords: teachers questions, types of questions, English language learning class

\section{A. Introduction}

Asking questions is one of the ways to get students' attention and participation in the classroom. Questions as the utterance used in questioning can be defined as any sentences which have interrogative form or function (Cotton, 2001:1). Asking question has an important role in teaching and learning process. Asking question is a conversation form in the classroom and it needs the understanding between speaker and listener (Syafryadin, et. al. 2020; Syafryadin, 2020). According to Herlinawati (2013) asking questions are necessary to use during teaching and learning activity because by asking questions teacher can guide the 
class, engage students with the content of the course, encourage participation and foster understanding. Morever McComas (2004) adds that questioning has deep implications for the way that studets receive and process information presented and discussed in class. Moreover, by asking questions, the teachers will get feedback from their student. The feedback is about their understanding about material or lesson that they have learn. In this case, teachers can "identify errors in their thinking about content and check students comprehension towards their learning objectives which can be represented by the students' responses to teachers' questions (Walsh and Sattes, 2012). Rosenshine (2012) also states that "questions allow a teacher to determine how well the material has been learned and wheter there is a need for additional instruction". According to Cole and Chan (1987) "students' learning is enhanced if questions are related to the full range of instructional objectives”. Those questions reflect to low and high order questions to be asked depends on the students' abilities, the instructional objectives to be achieved, and the purposes of the questioning. Wilen (1987) described that of the many methods of teaching, questioning is by far the one most commonly used at all grade levels and the teachers have long used questioning strategies to review, to check on learning, to explore thought processes, to explore problems, to find out different or various solutions, and to challenge students to depict on critical issues or values they had not previously think carefully.

Teacher's questions are not only in a theory, but also is used in the application of 2013 Curriculum (K-13) where in this curiculum, all educational levels use scientific approach in the teaching and learning process. There are five steps in the approach, such as : 1) Observing, 2) Questioning, 3) Collecting of information, 4) Associating, and 5) Networking (Daryanto, 2013). Teachers help their students prepare for the next stage of their education and personal growth. Many of the duties of the professional teacher are the same regardless of the grade level of the students. Both Clement (2002) and Seifert (1999) point out that becoming a professional teacher is a process that takes time to master. Stronge (2002) categorized the attributes, behaviors, and attitudes of effective teachers into six major areas: prerequisites of effective teachers, the teacher as a person, classroom management and organization, organizing for instruction, implementing instruction, and monitoring student progress and potential.

Researcher use types according to Taxonomy Blooms revised by Anderson and Krathwohl (2001) assist teachers in recognizing their various levels of question asking (among other things). The system contains six levels, which are arranged in hierarchical 
form, moving from the lowest level of cognition (thinking) to the highest level of cognition (or from the least complex to the most complex), there are remembering, understanding, applying, analyzing, evaluating, creating.

Pratiwi and Yulia (2018) they finding of they research showed that both teachers pose more questions of knowledge level than other levels, and the teachers used various techniques to modify their questions when the students did not give the response. Adibah (2012) found that the teacher used six out of seven question types; they were: knowledge, comprehension, application, inference, analysis, and synthesis questions. Vebriyanto (2015) discovered that the teacher utilized certain types of questions. revised by Anderson and Krathwohl (2001). From the previous studies above, all previous studies were the subject only used by teachers. Furthermore, two of the previous studies used questions type according of taxonomy blooms previous and studies use descriptive qualitative. Meanwhile, this research focuses on the questions of professional teachers used types according to Taxonomy Blooms revised by Anderson and Krathwohl (2001). This research used a descriptive quantitative.

The study was conducted in SMA N 5 Kota Bengkulu. Researcher think this school exact to this research because this school one of the best schools in Bengkulu and is a national standard. Type of questions plays an important role in teaching and learning process in order to give the students more chances to participate in learning activity and improve their thinking skills. Many teachers do not yet understand that there are many types of questions in teaching that can make students think more and make the learning process more organized and make teachers and students communicate and interact more. But asking questions that guide students against productive thinking is not a simple task, teacher has to have a good concept and sense of the subject matter so that the teacher can ask the suitable questions to help students fuse the different draft into a conceptual structure or frame of interconnecting perception rather than the present (Chin, 2007). This study aimed to find out the types of questions professional teachers used according to Taxonomy Blooms revised by Anderson and Krathwohl (2001) and dominant types of questions professional teachers used in the English classrooms.

This study reports the types of teachers' questions used by English teachers in the classroom. The result of this study may encourage English teachers to employ certain types of question that help students to engage in mutual interaction within classroom, which in turn can lead to the progress of students' language learning. Furthermore, the writer expects that this study could give contribution to the knowledge of English language teaching in 
Indonesia. Also, it is hoped that the study would give additional reference to the development of English teaching methods particularly in Indonesia and to further research with similar topic.

From the explanation above, type of questions plays an important role in teaching and learning process in order to give the students more chances to participate in learning activity and improve their thinking skills. Therefore, the researchers investigated teachers' questions used by English teachers of SMA N 5 Kota Bengkulu.

\section{B. Methodolgy}

This study describes the types of teacher questions used by teachers in English language classroom. This research used by using a descriptive quantitative method. According to Aggarwal (2008), descriptive quantitative research is devoted to the gathering of information about prevailing conditions or situations for the purpose of description and interpretation. This type of research is truly focused on describing and explaining sometimes in a somewhat definitive manner the phenomenon under investigation (Creswell, 2005) because of this singular perspective, quantitative research operates under widely agreed on steps that guide the research process (Fraenkel et al., 2012). The researcher chose descriptive quantitative method because it is an appropriate method that allowed the researcher to examine in more detail and deeply about an issue. In addition, the researcher conducted quantitative research because the research needs know to refer to research questions of the professional teachers' questions at SMA N 5 Kota Bengkulu. Data of this study were teachers' question during the whole of the teaching-learning process. This research was conducted in the tenth grade at SMA N 5 Kota Bengkulu. Researcher analyzed this study data gained from the obsevation checklist. According to Jackson (2008) checklist is a tally sheet on which the researcher records attributes of the participants' particular behaviors were observed. In this research, the researcher has used a checklist in collecting data through classroom observation. The obsevation checklist of the teachers questions what the type of the teachers questions used in six types according by Taxonomy blooms revised by Anderson and Krathwohl (2001). To get data of teacher questions, this research involved two professional English teachers. In this study, the teachers were coded as Teacher A and Teacher B.

There were some techniques which the researcher used to collect the data; they were observation and video recording. In analyzing data from observation and video recording, The researcher made description of each observation based on the notes taken during the 
observation. The result of the description was used to get more detail context when classify types of questions and interpreting the meaning of certain utterance. After having the description, the next step was transcribing the data from video-recording. After having the transcription, then the researcher classified the utterance into two categories, teacher questions category and modification of teacher question. Researchers are also assisted by coresearchers to check the validity of the data. Validity is a test measure what it is supposed to be measured. Validity means the degree to which a measuring instrument is precise and accurate in carrying out its measuring task. After all the utterances categorized, the researcher classified all the teacher's questions based on the taxonomy of question adapted from the framework of Taxonomy blooms revised by Anderson and Krathwohl (2001).

\section{Results and Discussion}

\section{Results}

\section{a. The Types of Teachers Questions Used in the Classroom}

The researcher presented the data findings of the first research question. The first research question was related to the types of questions used by the professional English teachers in the classroom. In classifying the types of questions based on Taxonomy Blooms' revised by Anderson and Krathwohl (2001) by using a checklist the researcher found that there were some question types used by English professional teachers and some question types were not used by the English professional teachers in four meetings of English lesson. The researcher presented the data finding of the types of questions used by the professional English teachers in the table as follows :

Table 1. The frequency and the percentage of professional English teachers' oral questions in four meetings used by the two professional teachers of teaching and learning activities

\begin{tabular}{|c|c|c|c|c|c|c|c|}
\hline \multirow{3}{*}{ No. } & \multirow{3}{*}{$\begin{array}{l}\text { Classification of } \\
\text { Question Types }\end{array}$} & \multicolumn{4}{|c|}{ Frequency } & \multirow{3}{*}{ Total } & \multirow{3}{*}{ Percentage $(\%)$} \\
\hline & & \multicolumn{2}{|c|}{$\begin{array}{c}\text { Teacher } \\
\text { A }\end{array}$} & \multicolumn{2}{|c|}{$\begin{array}{c}\text { Teacher } \\
\text { B }\end{array}$} & & \\
\hline & & 1 & 2 & 1 & 2 & & \\
\hline 1. & Remembering & 9 & 25 & 22 & 17 & 73 & $54.48 \%$ \\
\hline 2. & Understanding & 19 & 15 & 8 & 6 & 48 & $35.82 \%$ \\
\hline 3. & Applying & - & - & - & - & - & - \\
\hline 4. & Analyzing & 3 & 9 & - & 1 & 13 & $9.70 \%$ \\
\hline 5. & Evaluating & - & - & - & - & - & - \\
\hline 6. & Creating & - & - & - & - & - & - \\
\hline & Total & 31 & 49 & 30 & 24 & 134 & $100 \%$ \\
\hline
\end{tabular}


The researcher found that there were three types of questions used by two English professional teachers' in SMA N 5 Kota Bengkulu. In asking questions activities, the teachers used remembering, understanding, and analyzing questions. On the other hand, in asking questions toward students in the classroom, the teachers did not use the types; applying, evaluating, and creating question.

\section{b. The Dominant Types of Teachers Questions Used in the Classroom}

The researcher found that the two proffesional English teachers used 133 questions to students of SMA N 5 Kota Bengkulu. Based on the analysis of the researcher toward the teachers' questions, the researcher found that the dominant questions tyoe used by proffesional English teachers was remembering questions during four meetings of English lesson. The result of the research can be seen in the following table:

Table 2. The frequency and the percentage of professional English teachers' oral questions in four meetings used by the two professional teachers of teaching and learning activities

\begin{tabular}{|c|c|c|c|}
\hline No. & Classification of Question Types & Frequency & Percentage (\%) \\
\hline 1. & Remembering & 73 & $54.48 \%$ \\
\hline 2. & Understanding & 48 & $35.82 \%$ \\
\hline 3. & Applying & - & - \\
\hline 4. & Analyzing & 13 & $9.70 \%$ \\
\hline 5. & Evaluating & - & - \\
\hline 6. & Creating & 134 & - \\
\hline & Total & & $100 \%$ \\
\hline
\end{tabular}

Based on calculation of each question type in table 2, that the dominant oral question types use by proffesional English teachers in four meetings during the teaching and learning process was remembering questions. The remembering questions was the highest percentage among all questions types with 73 time occcurred (54.48\%). The second percentage level was understanding question in which the teachers have used it for 48 times (35.82\%). The third level wa anlyzing questions with 13 occurrences (9.70\%). Additionally, there were three question types which have not been used by the two proffesional English teachers such as applying, evaluating, and creating. 


\section{Discussion}

\section{a. The Types of Questions Teachers Used in the Classroom}

1) Remembering Question

All English professional teachers in SMA 5 Kota Bengkulu used remembering questions. these findings indicate that professional teachers ask the type of remembering questions for students to recall or recognize information to students. This finding confirmed the finding of Pratiwi and Yulia (2018) used knowledge questions, both teachers have a lack of skills in teaching English language, especially in giving a question to students. Teachers only focused on recognizing and recalling students' knowledge. This result finding is in line with the study from Adibah (2012) in SMA Al-Yasii Pasuruan, her found that knowledge questions used by the English teacher in this case knowledge questions, in every meeting observed. As mentioned in result Vebriyanto (2015) it was discovered that the teacher utilized referential-open questions and display-closed questions. Questions that are categorized as display/closed questions were widely used for checking students' understanding of the questions of the material that categorized as referential/open questions were widely used for looking for certain information from the students. Sabaruddin (2016) explained that teachers did realize that they should try to involve the student in interaction by employing clarification and information question almost equally to comprehension questions even thought the purpose of those questions does not seem to request further information, but simply a repetition or repair of the given information. This explanation was also supported by Thompson (as cited in Walsh, 2011) stated that the need for language teaching professional to ask appropriate questions and emphasizes the complexity attached to good question.

\section{2) Understanding Question}

This finding suggested that the understanding question that used English professional teachers in SMA 5 Kota Bengkulu. The teacher gives questions about their understanding of the learning material, the students can answer in his or her own words by stating facts or by characterize, explain, and translate to get the new vocabulary. This finding aligned with several other prior studies Pratiwi and Yulia (2018), they found that teachers also used comprehension question, the ability to understand the meaning in the material, the students can understand the teacher teaching in the classroom. Sabaruddin (2016) explained that They were found the employ significantly more display questions than referential question during EFL instruction. Analyzing the effect of teaching experience on the use of questions, the 
result suggests that despite the fact that there was a positive movement towards the use of clarification and confirmation question.

\section{3) Applying Question}

In this type teacher not used applying questions, applying means carrying out or using a procedure in a particular situation and it is related to procedural knowledge. Problem is an assessment in which the procedure to solve it is still unidentified by students so, they have to find the procedure to solve the problems. The application question is the low level cognitive, this is the standard question for the senior high school level, but the teacher does not use this type in every meeting. Time was one of the things that affected teachers in asking questions. it is found that students were not interested in learning English language, and they have low motivation in learning English language. It can be seen from their response to the teachers' questions. This finding is different from the study from Adibah (2012) in SMA Al-Yasii Pasuruan, which revealed that the teachers asked display questions more frequently than referential questions. The difference lies in the cognitive level of each question. Display questions are considered lower-level questioning.

\section{4) Analyzing Question}

The next type is analyzing question. In this type, the teacher breaks down a concept or idea into parts and show relationships among the parts. Allow time for students to examine concepts and ideas and to break them down into basic parts. This finding suggested that teachers used this type to make students think to classify material. It is supported by (Huitt, 2011), it requires the students to distinguish, classify, and relate the assumptions, evidence, hypothesis, and structure of a statement or question. It is in line with Adibah (2012) the teacher asked the student to differentiate one thing to another. Such a question is used to break down something into parts or relate parts to the whole. Another study that found different result is Pratiwi and Yulia (2018), students' background is also influenced the students' competence in learning English language, such as their parents' educational background and profession. The situation of teaching and learning English languages also influenced the teachers in asking questions in the classroom. 
5) Evaluating question

This research not used these types It can be that the teachers' questions are influenced by teachers' competence in teaching English, students' competence, the situation of teaching and learning English language, and the material of the lesson. It is in line with the result of research by Pratiwi and Yulia (2018), who reported that the presence of significant positive relationship between teacher effectiveness in lesson explanation, the method in asking questions, and their competence in teaching. Such questions are used to make a judgment of good and bad, right or wrong, according to some set of criteria, and state why (Brown, 2007: 172). The teacher did not use any evaluation questions because the topics discussed in the three meetings might not suit the use of evaluation questions.

\section{6) Creating Question}

The last type is creating questions, This process is the highest level among the other previous cognitive level according to Taxonomy Blooms revised by Anderson and Krathwohl (2001), It cannot really stimulate students' initiatives, nor can it develop their interactive competence. However, putting the skill into practice should not be the final aim of the English teacher. They should devise questions carefully, considering the specific situations and using them correctly in class.

It is in line with Adibah (2012) in SMA Al-Yasii Pasuruan, creating questions thet emerged in the first meeting once and the second meeting for five times. Such questions require higher-level thinking or reasoning skills since they belong to referential questions (McNeil, 2010). The teacher that, she did not ask many high-level questions like inference, analysis, synthesis, and evaluation questions because the topic of the study was still in the first unit discussing the descriptive text. For further topics such as narrative texts, she would use more referential questions that require a higher cognitive level.

\section{b. The Dominant Types of Questions Teachers Used in the Classroom}

The dominant types of questions used English professional teachers in teachinglearning class is remembering questions. This finding confirmed the finding of Pratiwi and Yulia (2018) who reported that the dominant question of teachers used is knowledge question. There were several factors that might influence the use of certain question types by the teacher; they were: the objectives of the lesson, the variety of tasks, and the teacher's purpose in asking questions. First, the objectives of the lesson determined the use of certain 
question types by the teacher. The use of appropriate question types will lead to the success of learning activities. Hence, the objectives of lesson should be designed thoroughly based on the desired competence and students' proficiency level. It was found that the English teacher frequently used remembering questions to check students' remember. In addition, this type of question is employed to elicit a factual answer, recall tests, and recognize information (Brown, 2007).

\section{Conclusion and Suggestion}

\section{Conclusion}

This study aimed to find out the types of questions professional teachers used according to Taxonomy Blooms revised by Anderson and Krathwohl (2001) and dominant types of questions professional teachers used in the English classrooms. After doing the research, it can be concluded that there were three types of questions used by two English professional teachers' in SMA N 5 Kota Bengkulu, they are remembering, understanding, and analyzing questions. In asking questions toward students in the classroom, the teachers did not use the types; applying, evaluating, and creating questions.

Moreover, Questions Used by Teacher A and B in Two Meetings of Teaching English. Teachers used some questions in the teaching and learning process for two meetings. From English professional teachers', the researcher concluded that teachers mostly used remembering questions type. It showed that remembering question were the dominant oral questions type used by teachers in the English teaching learning process.

\section{Suggestion}

The teachers should be even more varied in giving questions to students. Teachers showed dominantly in presenting elements that are closely related to lower-order thinking skills rather than higher-order thinking skills. To solve this issue, the English teachers as professional teachers by giving extra information about tasks that contain higher order thinking skill and giving extra classroom activities that related to higher order thinking skill. The teachers also have to guide the students to know higher order thinking skills deeply. It is possible to add some supplemental materials to make it balance.

It is suggested that the next researchers who want to conduct research in the same field do further research about the teachers' question in the different object and context. They can use this study as their guide to do further research, and as a reference to conduct further research that is related to using teacher questions in the English teaching process. 


\section{References}

Adibah. (2012). An analysis of questions used by an english teacher in classroom (A case study at the 10th grade of SMA Al-Yasini Pasuruan 2011/2012). Journal Anglicist $1(1), 2$.

Aggarwal, Y.P. (2008). Science of education Research. Nirmal Book Agency.

Brown, H. Douglas. (2007). Teaching by principle: an interactive approach to language pedagogy. New York: Longman.

Chin, C. (2007). Learning in science: what do students' questions tell us about their thinking?. Education Journal, 29(2).

Cole, P.G., \& Lorna, K.S.C. (1987). Teaching principles and practice. Sydney: Prentice Hall.

Creswell, J.W. (2005). Educational research. planning, conducting, and evaluating quantitative and qualitative reserach, second edition. New Jersey: Pearson Merrill Prentice Hall.

Cotton, K. (2001). Classroom questioning. School Improvement Research Series SIRS, Northwest Regional Educational Laboratory.

Fraenkel, J.R., \& Norman E.W. (2012). How to design and evaluate research in education 8th edition. Boston: McGraw-Hill Higher Education.

Herlinawati, M.S. (2013). A study of english teachers' questions in teaching english at a selected vocational school in Kota Bengkulu. Bengkulu.

Johnson, K.E. (1995) Understanding communication in second language classrooms. Cambridge: Cambridge University Press.

Khoiri. Noviyenti, L., \& Edy, S. (2019). Indonesian teachers technique in teaching English at Chariyatham Suksa Foundation School, Chana, Songkhla, Thailand. Journal of English Education and Teaching (JEET). 3 (4).

Ma, X. (2008). The skills of teacher's questioning in English clasess. International Education Studies, 1, 92-100.

McComas, B. (2004). Enhance learning through better questions. Retrieved from http://cet.usc.edu/resources/teaching_learning/docsasking_better_questions.pdf

Pratiwi, E., \& Yulia, Y. (2018). An analysis of teachers' questions in English language classroom: a case study in year 10 of SMK N 1 Nunukan. Journal of English Language and Pedagogy.

Rosenshine, B. (2012). Principle of instruction: research based strategies that all teachers should know. Retrieved from http://ww.aft.org/pdfsamericaneducator/spring2012/Rosenshine.pdf 
Sabaruddin. (2016). Forms and function of English teachers' questions at public juior high schools in Bengkulu city a discourse study of non-native teacher talk. Journal of Linguistics ang Language Teaching, 3 (1): University of Bengkulu.

Seifert, K. L. (1999). Reflective thinking and professional development: A primer. Boston: Houghton Mifflin.

Syafryadin, Dian, E. C. Wardhana., Eka Apriani., \& Noermanzah. (2020). Maxim Variation, Conventional, and Particularized Implicature on Students' Conversation. International Journal of Scientific and Technology Research, 9(2) https://doi.org/10.31219/osf.io/cza8y.

Syafryadin, S. (2020). Students' strategies in learning speaking: experience of two indonesian schools. Vision: Journal for Language and Foreign Language Learning, 9(1), 33-46.

Vebriyanto, D.A (2015). Teachers questions in EFL classroom interaction, Walisongo state institute for islamic studies, Semarang. Retrieved fromhttp:eprints.walisongo.ac.id/1652/.

Walsh, J.A., \& Sattes, B.D., (2012). Thinking through quality of questioning, activity packet. salesmanship club youth and family centers. Retreived from http://brainchildblog.com/wpcontent/uploads/2012/02Walsh-Sattes PDF.pdf.

Wilen, W. (1987). Questions, questioning techniques, and effective teaching. Washington, D.C: National Education Association. 